\title{
Changes in temperature of a Plinthosol cultivated with sugarcane under straw levels
}

\author{
João Carlos Rocha dos Anjos', Aderson Soares de Andrade Júnior²*, \\ Edson Alves Bastos², Everaldo Moreira da Silva'
}

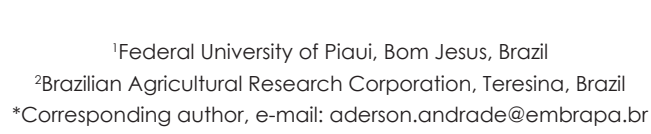

\begin{abstract}
Soil temperature is affected by its coverage and influences sugarcane productivity. Changes in temperature were assessed in a Plinthosol cultivated with sugarcane under different straw levels, as well as its reflection in stalk productivity, aiming at determining the maximum amount of straw to be removed for other purposes without damaging soil thermal conditions necessary for the crop. The experimental design was a split-plot randomized block design with four replications, with assessment periods of soil temperature arranged in the main plots, straw levels $\left(0,4.2,9.5,13.0\right.$, and $\left.18.4 \mathrm{Mg} \mathrm{ha}^{-1}\right)$ arranged in the subplots, and two measuring depths of soil temperature $(0.05$ and $0.10 \mathrm{~m})$ arranged in the sub-subplots. Soil temperature was obtained by T-type thermocouples (copper/constantan). Soil thermal amplitude underwent oscillations as a function of straw levels, especially at a depth of $0.05 \mathrm{~m}$. The maintenance of $9.5 \mathrm{Mg} \mathrm{ha}^{-1}$ of straw provided an increase of $11.1 \%$ in stalk productivity. Values above $9.5 \mathrm{Mg} \mathrm{ha}^{-1}$ of straw can be removed from the field for other purposes without impairing soil thermal conditions required for the crop.
\end{abstract}

Keywords: Soil and water management, no-tillage, thermocouple

Soil temperature is responsible for the maintenance of its biochemical processes (Marin et al., 2008). However, its amplitude depends on factors such as soil depth, levels of soil coverage with straw, and live plants (Chabat, 2010), which when properly managed can favor agricultural production environments (Mulumba \& Lal, 2008; Galdos et al., 2009; Santana et al., 2011).

The amount of straw obtained from the sugarcane harvest without burning, estimated from 10 to $30 \mathrm{Mg} \mathrm{ha}^{-1}$ (Christoffoleti et al., 2007), has several applications in the sugaralcohol plants, such as electricity production, boiler heating, and the production of secondgeneration ethanol (Lima \& Natalense, 2010). On the other hand, the straw left on the soil surface has a primordial function in its productivity and sustainability (Santana et al., 2011; Fortes et al., 2012; Aquino \& Medina, 2014). The basic question to be answered is: What is the proportion of straw that should be removed from the field for energy purposes without affecting long-term soil sustainability?

In this sense, this study aimed to assess the changes in temperature of a Plinthosol (Plintossolo Argilúvico, Brazilian Soil Classification System) cultivated with sugarcane under different straw levels and its reflection in stalk productivity, aiming at determining the maximum amount of straw to be removed for other purposes without 
damaging the soil thermal conditions necessary for the crop.

For this, an experiment was carried out in an area of the COMVAP Mill - Açúcar e Álcool Ltda. $\left(04^{\circ} 35^{\prime} 09^{\prime \prime} S, 42^{\circ} 51^{\prime} 51^{\prime \prime} \mathrm{W}\right.$, and altitude of 52 m) located in União, a micro-region of Teresina, Piauí State, Brazil, from July 2013 to July 2014. Regional climate is ClsA'a', characterized as a mega-thermal, dry sub-humid climate with moderate water surplus in the summer and an annual average rain of $1343 \mathrm{~mm}$ (Bastos \& Andrade Junior, 2013). The soil was classified as a Plinthosol (Plintossolo Argilúvico', Brazilian Soil Classification System) with the following physical and chemical characteristics: a) depth of 0 to 0,05 m: textural class = sandy loam, soil density $(\mathrm{Ds})=1.43 \mathrm{Mg} \mathrm{m}^{-3}$, soil organic matter $(\mathrm{SOM})=$ $7.6 \mathrm{~g} \mathrm{~kg}^{-1}$, percentage of base saturation $(\mathrm{V} \%)=$ $55.5 \%$, acidity $\left.(\mathrm{H}+\mathrm{Al})=2.69 \mathrm{cmol}_{\mathrm{c}} \mathrm{dm}^{-3} ; \mathrm{b}\right)$ depth of 0.05 to $0.1 \mathrm{~m}$ : textural class $=$ sandy loam, $\mathrm{Ds}=$ $1.53 \mathrm{Mg} \mathrm{m}^{-3}, \mathrm{SOM}=3.35 \mathrm{~g} \mathrm{~kg}^{-1}, \mathrm{~V} \%=42.3 \%, \mathrm{H}+\mathrm{Al}$ $=3.3 \mathrm{cmol}_{\mathrm{c}} \mathrm{dm}^{-3}$.

Sugarcane straw production, cultivar SP813250, 4th leaf cycle, was uniformly distributed

1 Soil profile classified by the researcher Francisco de Brito Melo, Embrapa Mid-North, Teresina, PI. over the soil surface according to the proportions of $0,25,50,75$, and $100 \%$ coverage of the cultivated area. These proportions corresponded to the application of $0,4.2,9.5,13.0$, and $18.4 \mathrm{Mg}$ ha ${ }^{-1}$ of dry straw.

Soil temperature monitoring was carried out at depths of 0.05 and $0.1 \mathrm{~m}$ at each experimental plot using T-type thermocouples (copper/constantan), with lengths of 10 and 25 $\mathrm{m}$ and expansion joints encapsulated in stainless steel terminals and the other end connected to a CR10X data logger through two AM16/32 multiplexers (Campbell Scientific Inc.). The system was programmed to perform readings every 10 minutes, recording the means every 30 minutes between 217 and 360 days after cutting (DAC) the sugarcane.

The experimental design was a split-plot randomized block design with four replications, with assessment periods in the plots (Table 1), straw levels in the subplots, and the two measurement depths in the sub-subplots 10.05 and $0.1 \mathrm{~m})$. The experimental plots were $10 \mathrm{~m}$ wide and $15 \mathrm{~m}$ long. Sugarcane was cultivated at a spacing of $1.4 \mathrm{~m}$ between rows, with fifteen buds per linear meter.

Table 1. Assessment periods of soil temperature and their respective intervals of days after cutting the crop (DAC) throughout the development cycle of sugarcane. COMVAP Mill, União, PI, Brazil, 2013/2014.

\begin{tabular}{cccccc}
\hline Period & DAC & Period & DAC & Period & DAC \\
\hline 1 & $217-224$ & 7 & $265-272$ & 13 & $313-320$ \\
2 & $225-232$ & 8 & $273-280$ & 14 & $321-328$ \\
3 & $233-240$ & 9 & $281-288$ & 15 & $329-336$ \\
4 & $241-248$ & 10 & $289-296$ & 16 & $337-344$ \\
5 & $249-256$ & 11 & $297-304$ & 17 & $345-352$ \\
6 & $257-264$ & 12 & $305-312$ & 18 & $353-360$ \\
\hline
\end{tabular}

Daily soil temperatures were calculated as follows: a) maximum temperature (Tmax) - maximum value recorded among the 48 daily records; b) minimum temperature (Tmin) - minimum value recorded among the 48 daily records; and c) daily soil thermal amplitude - the difference between daily Tmax and Tmin.

In order to assess the effect of soil temperature on sugarcane development, the leaf area index (LAI) (Figure 1), estimated monthly, was calculated between 217 and 360 DAC (Table 1) from the leaf area (LA) of plants divided by the area occupied by a linear meter of crop $\left(1.4 \mathrm{~m}^{2}\right)$. For LA calculation, the methodology described by Hermann \& Câmara (1999) was followed. Stalk productivity (TSH, tons of sugarcane per hectare) was obtained by weighing the stalks of each plot and dividing the value by the plot area $\left(150 \mathrm{~m}^{2}\right)$.

The means of LAI and TSH were submitted to the Tukey's test at 5\% probability using the software Assistat 7.7 (Silva \& Azevedo, 2016). Soil thermal amplitude data were submitted to the regression analysis through the software TableCurve 2D v5.

A reduction was observed in soil thermal amplitude (TA) as straw levels increased on the soil surface when compared to the uncovered soil, mainly in the soil surface depth (Figure 2). 
This reduction was more pronounced in the early stages (Figures $2 \mathrm{~A}$ and $2 \mathrm{~B}$ ) than in the final stages (Figures 2C and 2D). This behavior is probably due to the isolated effects of soil coverage on the dynamics of maximum and minimum soil temperatures.

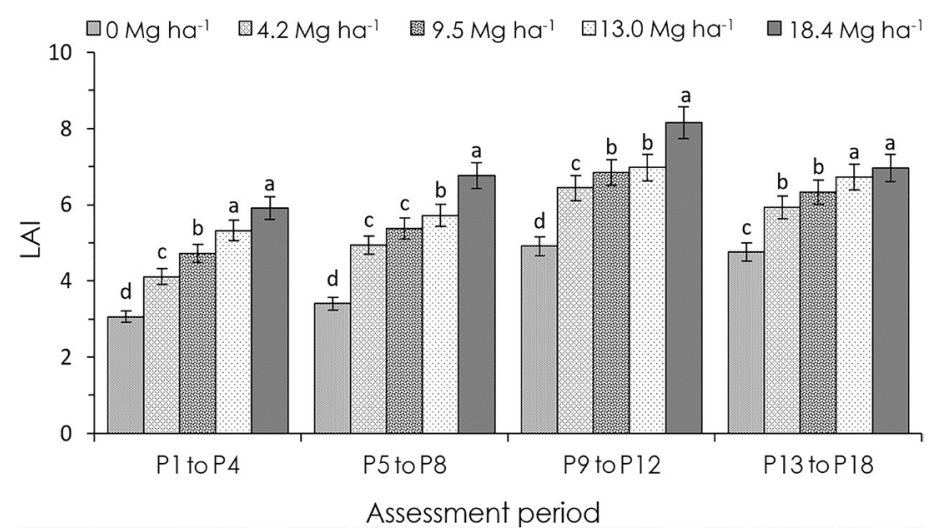

Figure 1. Leaf area index (LAI) of sugarcane cultivated in soil covered with different straw levels in the eighteen assessment periods throughout the cultivation cycle. COMVAP Mill. União, PI, season 2013/2014. Bars with the same letters at each period interval do not differ statistically from each other by the Tukey's test at $p=0.05$ of probability.
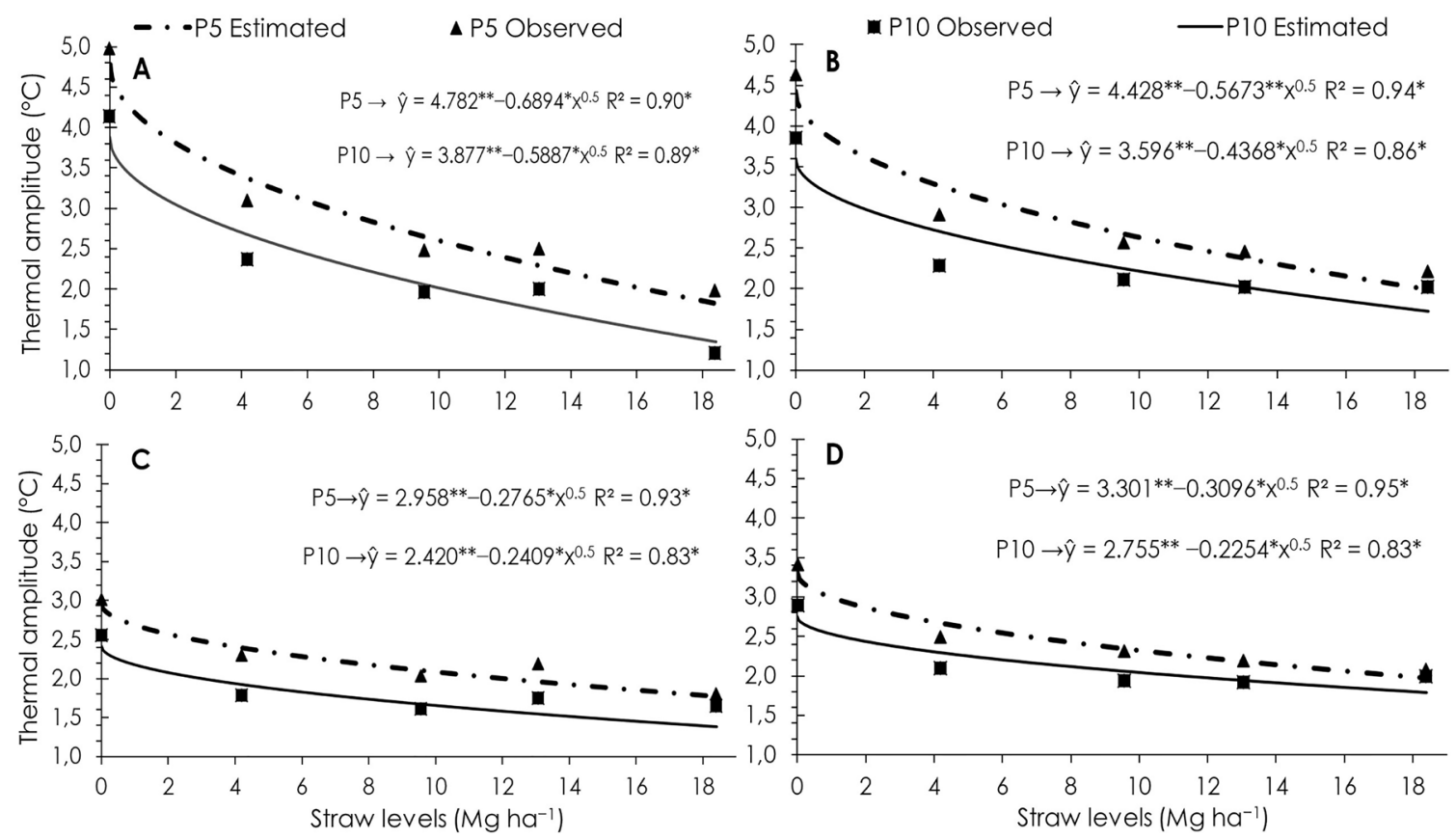

Figure 2. Daily thermal amplitude of a Plinthosol at a depth of 0.05 (P5) and $0.10 \mathrm{~m}$ (P10) at the assessment periods 4 (A), 6 (B), 11 (C), and 17 (D) as a function of straw levels. COMVAP Mill, União, PI, Brazil, 2014. * and ** indicate significances at probability levels of $0.05 \geq p>0.01$ and $p \leq 0.01$, respectively, at $95 \%$ confidence level; P5 and P10 = depths of 0.05 and $0.10 \mathrm{~m}$, respectively.

Silva et al. (2006) observed that as plants grow, soil thermal amplitude is reduced, maintaining the thermal conditions favorable to life in the soil. Knies (2010) used 3 and $6 \mathrm{Mg} \mathrm{ha}^{-1}$ of black oat residues on the soil surface cultivated with corn and observed a reduction in TA of up to $6.3{ }^{\circ} \mathrm{C}$ in a sandy textured Ultisol (Argissolo Vermelho Distrófico, Brazilian Soil Classification System) under subtropical humid climate. Chabat (2010) observed that the addition of 4.0
$\mathrm{Mg} \mathrm{ha}^{-1}$ of plant residues over a typical Brunosol cultivated with soybean and under a humid temperate climate reduced TA by up to $40 \%$ at depths of 0.05 and $0.10 \mathrm{~m}$.

The mathematic model that fit the experimental data was the decreasing non-linear polynomial (root model), indicating that the TA does not vary linearly as straw levels distributed on the soil surface increase, which is different from the results found by Knies (2010), Chabat 
(2010), and Bragagnolo \& Mielniczuk (1990), who obtained a linear response of AT with the applied straw levels. This difference may be related to the coverage level used in our study be higher than those found by other authors.

In addition, TA reduced $1.4^{\circ} \mathrm{C}$ with a straw addition of $4.2 \mathrm{Mg} \mathrm{ha}^{-1}$ when compared to the uncovered soil, while an addition of $9.5 \mathrm{Mg}$ $\mathrm{ha}^{-1}$ led to a reduction of $2.1^{\circ} \mathrm{C}$. The application of $13.0 \mathrm{Mg} \mathrm{ha}^{-1}$ of straw led to a reduction in AT, in relation to the uncovered soil, of $2.5^{\circ} \mathrm{C}$, i.e. AT reduced very little (only $0.4^{\circ} \mathrm{C}$ ) with the addition of more $3.5 \mathrm{Mg} \mathrm{ha}^{-1}$ of straw. Thus, soil thermal amplitude underwent oscillations as a function of straw levels, especially at a depth of $0.05 \mathrm{~m}$ and the initial stage of leaf development of the crop.

A significant difference $(p<0.05)$ was observed between the averages of stalk productivity (TSH) of the fourth leaf sugarcane cultivated under uncovered and $100 \%$ straw level (Figure 3). However, no significant difference ( $p>0.05$ ) was observed between the other straw levels. The highest differences in TSH were obtained between treatments without straw coverage (65.7 $\left.\mathrm{Mg} \mathrm{ha}^{-1}\right)$ and with total coverage $\left(87.7 \mathrm{Mg} \mathrm{ha}^{-1}\right)$, with a gain of $33.44 \%\left(22 \mathrm{Mg} \mathrm{ha}^{-1}\right)$ of TSH.

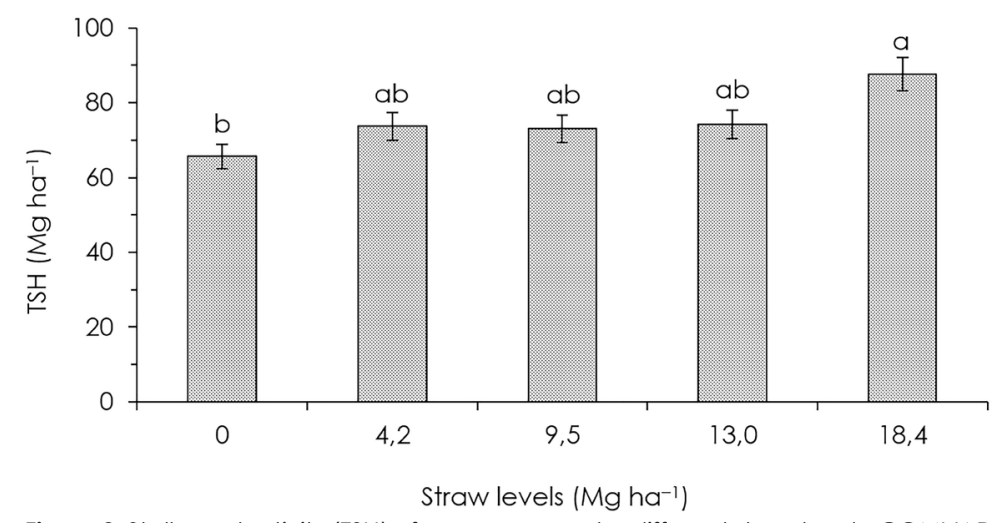

Figure 3. Stalk productivity (TSH) of sugarcane under different straw levels. COMVAP Mill. União, PI, Brazil, July 2013 to July 2014. Bars with the same letters do not differ statistically from each other by the Tukey's test at 5\% probability. LSD $=16.9$ and $\mathrm{CV} \%=10.06$.

The straw level of $4.2 \mathrm{Mg} \mathrm{ha}^{-1}$ provided a gain of $12.18 \%\left(8 \mathrm{Mg} \mathrm{ha}^{-1}\right)$ of TSH when compared to the treatment without straw, presenting a better response of TSH in relation to the straw level maintained on the soil surface since from this level, a straw addition of $14.2 \mathrm{Mg} \mathrm{ha}^{-1}$ was needed to reach a gain of $14 \mathrm{Mg} \mathrm{ha}^{-1}$ of TSH. This result reflects an improvement in soil thermal conditions, mainly in the reduction of the thermal amplitude promoted by straw levels either by the increase in soil natural nutrition promoted by a higher microbial activity or the reduction in water loss, in addition to its protection against soil erosion promoted by the improvement of its aggregates.

Aquino \& Medina (1014) observed gains of $28 \mathrm{Mg} \mathrm{ha}^{-1}$ when assessing the effects of different straw levels on the productivity of the sugarcane plant in an Oxisol (Latossolo Vermelho eutroférrico, Brazilian Soil Classification System).
However, these authors did not find significant increases of this variable between treatments with $5 \mathrm{Mg} \mathrm{ha}^{-1}$ (25\%), $10 \mathrm{Mg} \mathrm{ha}^{-1} 1$ (50\%), and $15 \mathrm{Mg}$ $\mathrm{ha}^{-1}(75 \%)$ of straw and indicated the level of $50 \%$ as being enough to promote an improvement in crop productivity, with no significant gain above this straw level. Tavares et al. (2010) observed a productivity gain of successive sugarcane cultivation without burning and associated it with a reduction of soil thermal amplitude.

In our study, we recommend the maintenance of $25 \%$ of soil coverage $\left(4.2 \mathrm{Mg} \mathrm{ha}^{-1}\right.$ of straw), considering stalk productivity. However, the best straw effect on soil temperature was obtained with the maintenance of $50 \%$ of soil coverage (9.5 $\mathrm{Mg} \mathrm{ha}^{-1}$ of straw). Therefore, the maximum amount of straw to be removed for other purposes without affecting soil thermal conditions required for stalk productivity is $50 \%$ of the straw production from the previous cycle. 


\section{References}

Aquino, G.S., Medina, C.C. 2014. Produtividade e índices biométricos e fisiológicos de cana-deaçúcar cultivada sob diferentes quantidades de palhada. Pesquisa Agropecuária Brasileira 49: 173-180.

Bastos, E.A., Andrade Junior, A.S. 2013. Boletim agrometeorológico de 2012 para o município de Teresina, Piauí. Embrapa Meio-Norte, Teresina, Brasil. 38 p. (Documentos / Embrapa Meio-Norte, ISSN 0104-866X; 225).

Bragagnolo, L., Mielniczuk, J. 1990. Cobertura do solo por palha de trigo e seu relacionamento com a temperatura e umidade do solo. Revista Brasileira de Ciência do Solo 14: 369-374.

Chabat, M.M. 2010. Influência dos resíduos vegetais na superfície do solo na dinâmica de evaporação da água e temperatura do solo. 92f. (Dissertação de Mestrado em Ciência do Solo) - Universidade Federal de Santa Maria, Santa Maria, Brasil.

Christoffoleti, P.J., Carvalho, S.J.P., López-Ovejero, R.F., Nicolai, M., Hidalgo, E., Silva, J.E. 2007. Conservation of natural resources in Brazilian agriculture: implications on weed biology and management. Crop Protection 26: 383-389.

Fortes, C., Trivelin, P.C.O., Vitti, A.C. 2012. Longterm decomposition of sugarcane harvest residues in São Paulo state, Brazil. Biomass and Bioenergy 42: 189-198.

Galdos, M.V., Cerri, C.C., Cerri, C.E.P. 2009. Soil carbon stocks under burned and unburned sugarcane in Brazil. Geoderma 153: 347-352.

Hermann, E.R., Câmara, G.M.S. 1999. Um método simples para estimar a área foliar da cana-deaçúcar. STAB, Açúcar, Álcool e Subprodutos 17: 32-34.

Knies, A.E. 2010. Temperatura e umidade de um solo franco arenoso cultivado com milho. $104 \mathrm{f}$. Dissertação de Mestrado em Ciência do Solo) - Universidade Federal de Santa Maria, Santa Maria, Brasil.

Lima, M.A.P., Natalense, A.P.P. 2010. Necessidade de pesquisa básica para cana e etanol. In: Cortez, L.A.B. (Coord.). Bioetanol de cana-de-açúcar: P\&D para produtividade e sustentabilidade. Anais... São Paulo, Brasil. p.150-170.

Marin, F.R., Assad, E.D., Pilau, F.G. 2008. Clima e Ambiente: introdução à climatologia para ciências ambientais. Embrapa Informática Agropecuária, Campinas, Brasil. 127p. (ISBN: 978-85-86168-01-7).

Mulumba, L.N., Lal, R. 2008. Mulching effects on selected soil physical properties. Soil and Tillage Research 98: 106-111.

Santana, J.A.S., Vieira, F.A., Souto, J.S., Gondim, S.C., Fonseca. F.C.E. 2011. Decomposição da biomassa foliar de cana-de-açúcar em um Neossolo na região de Areia-PB. Revista Caatinga 24: 28-32.

Silva, F.A.S, Azevedo, C.A.V. 2016. The Assistat Software Version 7.7 and its use in the analysis of experimental data. African Journal of Agricultural Research 11: 3733-3740.

Silva, V.R., Reichert, J.M., Reinert, D.J. 2006. Variação na temperatura do solo em três sistemas de manejo na cultura do feijão. Revista Brasileira de Ciência do Solo 30: 391-399.

Tavares, O.C.H., Lima, E., Zonta, E. 2010. Crescimento e produtividade da cana planta cultivada em diferentes sistemas de preparo do solo e de colheita. Acta Scientiarum. Agronomy 32: 61-68. 